\title{
低血圧症を伴う慢性心不全の水分管理に 五苓散が有効であった一症例
}

\author{
松井 龍吉 ${ }^{\mathrm{a}}$ 山口 拓也 ${ }^{\mathrm{a}}$ 小林 祥泰 $\mathrm{b}$ \\ 長井 篤 $\mathrm{c}$ 山口 修平 \\ a 島根大学医学部附属病院神経内科, 島根, 广 693-8501 出雲市塩冶町89-1 \\ b 島根大学医学部附属病院, 島根, =693-8501 出雲市塩冶町89-1 \\ c 島根大学医学部附属病院臨床検查医学, 島根, = 693-8501 出雲市塩冶町89-1 \\ d 島根大学医学部内科学第三, 島根, =693-8501 出雲市塩冶町 89-1
}

\section{A Case of Chronic Heart Failure with Hypotension Successfully Treated with Goreisan}

\author{
Ryukichi MATSUI $^{\mathrm{a}} \quad$ Takuya YAMAGUCHI $^{\mathrm{a}}$ Shotai KOBAYASHI ${ }^{\mathrm{b}}$ \\ Atsushi NAGAI ${ }^{\mathrm{c}}$ Shuhei YAMAGUCHI ${ }^{\mathrm{d}}$
}

a Shimane University, Department of Neurology, Faculty of Medicine, 89-1 Enya-cho, Izumo-shi, Shimane 693-8501, Japan

b Shimane University, Faculty of Medicine, 89-1 Enya-cho, Izumo-shi, Shimane 693-8501, Japan

c Shimane University, Department of Laboratory Medicine, Faculty of Medicine, 89-1 Enya-cho, Izumo-shi, Shimane 6938501, Japan

d Shimane University, Department of Internal Medicine III, Faculty of Medicine, 89-1 Enya-cho, Izumo-shi, Shimane 6938501, Japan

\footnotetext{
Abstract

We report a case of chronic heart failure with hypotension, successfully treated with goreisan (Wu lin san). In this case, goreisan improved both the heart failure symptoms and water regulation. This 91-old woman had been receiving treatment for congestive heart failure, mitral regurgitation, aortic regurgitation and atrial fibrillation, and had undergone pacemaker implantation due to sick sinus syndrome. She underwent repeated hospitalization due to aggravation of her chronic heart failure. She was re-admitted because of systemic edema as well as exacerbation of heart failure symptoms which included pleural effusions. Blood pressure remained constant at about $80 / 50 \mathrm{mmHg}$. She was prescribed furosemide $40 \mathrm{mg}$. Thereafter, cerebral infarction complications arose. Therefore, it became difficult to increase the quantity of diuretics. We administered goreisan without change to the other oral medications. Many of her symptoms improved and the pleural effusion resolved without affecting blood pressure.

Goreisan is one representative herbal formula for promoting diuresis. In this case, it is thought that goreisan showed actions that influenced water regulation.

Key words : goreisan, heart failure, hypotension, pleural effusion

要旨

低血圧症を伴う慢性心不全の急性増悪症例に対して，五苓散を投与したところ心不全症状の改善と，その後の水 分管理が良好に保てた症例を経験した。症例は97歳女性。僧帽弁閉鎖不全，大動脈弁閉鎖不全，心房細動および洞 不全症候群によるペースメーカ植込み術を施行され外来にて加療中, しばしば心不全の増悪のため入退院を繰り返 していた。全身の浮腫, 胸水貯留など, 心不全症状の悪化により再入院となるが, 血圧は以前から80/50 $\mathrm{mmHg}$ 前 後と低值であり，利尿薬（フロセミド）を少量追加するが，経過中に脳梗塞を合併し，その後も血圧が低く，利尿 薬のさらなる追加が難しい状況であった。このためそれまでの内服薬を变更することなく， 口渇，尿量減少などを 目標に五苓散を追加したところ, 血圧に影響を与えることなく，尿量の増加とともに諸症状の改善と胸水の消失が 認められた。

五苓散は代表的な利水剤の 1 つである。本症例において血圧に影響を与えることなく，利水としての水分調節作 用を示したと考えられた。

キーワード : 五苓散, 心不全, 低血圧, 胸水貯留
} 


\section{緒言}

胸水貯留の原因の 1 つとして, うっ血性心不全に よるものがあり，心機能の改善を目標に塩分制限や 安静に加え, 薬剤として利尿薬，アンジオテンシン 変換酵素阻害薬 (angiotensin converting enzyme inhibitor: ACE 阻害薬)，強心薬などが用いられる。しか しこれらの薬剤を用いる場合には，電解質への影響 や，血圧を低下させたりする副作用について注意す る必要がある。

今回我々は低血圧症を伴う慢性心不全の脳梗塞合 併例に対し，五苓散を投与したところ，血圧に影響 を与えることなく，心不全症状の改善と，その後の 水分管理が良好に保てた症例を経験したので報告す る。

\section{症例}

91歳女性

主 訴：体動時呼吸苦, 浮腫

現病歴：僧帽弁閉鎖不全，大動脈弁閉鎖不全，慢 性心不全などにて外来受診中であったところ，90歳 時に洞不全症候群に対しペースメーカ植え込み術が 施行され，その後も外来にて内服薬治療が継続され ていた。経過中, 慢性心不全の急性増悪を繰り返し, $\mathrm{X}$ 年 6 月下旬の当院定期受診時, 体動時息切れ, 四 肢の浮腫が強くなり, さらに胸水貯留を認めたため 入院となる。

既往歴: 88歳, 89歳 慢性心不全急性増悪にて入 院加療。90歳 洞不全症候群に対してペースメーカ 植込み術。90歳時 慢性心不全急性増悪にて 3 回入 院。

家族歴：特記すべきことなし

生活歴：排便は 1 行/日。排尿は昼間 $4 \sim 5$ 回/日,
夜間 2 3 回/日。アルコール歴なし, 契煙歴なし。

現症：意識は清明。身長 $134.0 \mathrm{~cm}$, 体重 $37.7 \mathrm{~kg}$, 体温 $36.2{ }^{\circ} \mathrm{C}$ 。血圧 $125 / 71 \mathrm{mmHg}$ 。心拍数 $83 / \mathrm{min}$ 整。 $\mathrm{SpO}_{2} 97 \%$ (room air)。

結膜 貧血なし, 黄疸なし。皮膚はやや乾燥。表 在リンパ節の腫脹なし。甲状腺腫なし。肺音両側で 湿性ラ音あり, Wheezing あり，収縮期心雑音あり。 腹部平坦軟, 圧痛なし。肝脾腫なし。両側下腿に浮 腫性変化を認めた。四肢を中心に筋萎縮あり。神経 学的に明らかな異常所見なし。髄膜刺激症状なし。

和漢診療学的所見：

$<$ 自覚症状 $>$

全身倦怠感あり。手足のほてりなし。食欲は保た れている。口渇が強い。冷えの自覚なし。便通は良 好。

<他覚所見 $>$

体型は瘦せており，皮膚はやや浅黒く枯燥が見ら れ, 脱毛も認められた。舌は鮮紅。軽度萎縮, 圧痕 はなく, 著明に乾燥していた。顔面の色素沈着は見 られなかったが, 歯肉の暗赤化や口唇の暗赤化が認 められた。手掌紅斑なし。

脈は沈。腹力は弱く, 心下㾂鞕を認めた。胃部振 水音ははっきりせず，胸脇苦満なし。両側腹直筋の 緊張を軽度認め, 臍上悸が見られた。臍下悸や臍傍 圧痛，小腹不仁などは認められなかった。下肢に冷 えが見られた。

検査所見：入院時尿検査にて明らかな異常所見は なく，血液検査においては，BUN，クレアチニン の軽度上昇と, 脳性ナトリウム利尿ペプチド（brain natriuretic peptide : BNP） $3000 \mathrm{pg} / \mathrm{ml}$ と著明な上昇を 認めた（表 1 )。

表 1 入院時血液検査所見

\begin{tabular}{|c|c|c|c|}
\hline \multicolumn{4}{|l|}{ 血算 } \\
\hline \multicolumn{4}{|c|}{$5430 / \mu l$} \\
\hline RBC & 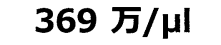 & ALP & 427 IU/I \\
\hline $\mathrm{Hgb}$ & $11.1 \mathrm{~g} / \mathrm{dl}$ & BUN & $29.9 \mathrm{mg} / \mathrm{dl}$ \\
\hline $\mathrm{Ht}$ & $34.1 \%$ & Crea & $1.37 \mathrm{mg} / \mathrm{dl}$ \\
\hline Plt & 15.5 万/ $\mu \mathrm{l}$ & ChE & $142 \mathrm{IU} / \mathrm{I}$ \\
\hline \multirow{2}{*}{\multicolumn{2}{|c|}{ 生化学·免疫 }} & CK & $84 \mathrm{IU} / \mathrm{I}$ \\
\hline & & $\mathrm{Na}$ & $142.9 \mathrm{mEq} / \mathrm{I}$ \\
\hline TP & $6.3 \mathrm{~g} / \mathrm{dl}$ & K & $3.41 \mathrm{mEq} / \mathrm{l}$ \\
\hline Alb & $3.5 \mathrm{~g} / \mathrm{dl}$ & Cl & $105.2 \mathrm{mEq} / \mathrm{I}$ \\
\hline T.bil & $0.61 \mathrm{mg} / \mathrm{dl}$ & CRP & $0.09 \mathrm{mg} / \mathrm{dl}$ \\
\hline GOT & $25 \mathrm{IU} / \mathrm{I}$ & BS & $116 \mathrm{mg} / \mathrm{dl}$ \\
\hline GPT & $22 \mathrm{IU} / \mathrm{I}$ & BNP & $3000 \mathrm{pg} / \mathrm{ml}$ \\
\hline
\end{tabular}




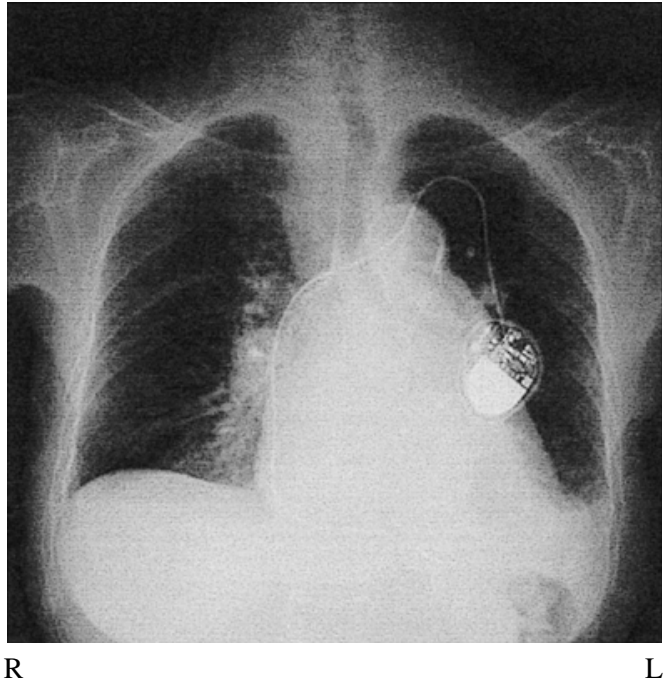

図 1 入院時胸部 $X$ 線検査

心胸郭比 $57.9 \%$ と心陰影の拡大を認めた。

心電図検査はペースメーカリズムであった。胸部 X 線検査に扮いて CTR57.9\% と心拡大を認めた（図 1 )。さらに胸部 CT 検査において, 両側胸水を認 め，葉間にも陰影が見られた $($ 図 $2-a) 。$

心臟超音波検査では僧帽弁逆流の重症度, 大動脈 弁閉鎖不全症の重症度はともに中等症であり, 左心 房の拡大は認められたものの, 左心室の動きは良好 であり，左室内径短縮率（\%fractional shortening:\% FS）35\%。左室駆出分画 (ejection fraction : EF) 63\% であった。

経過（図 3 ）：入院時の所見などから慢性心不全 の急性増悪と診断した。減塩食 $6 \mathrm{~g} /$ 日での塩分制限 を行い，入院後の収縮期血圧が $80 \mathrm{mmHg}$ 前後と低 值が続いていたことから，外来時フロセミド $40 \mathrm{mg}$ 内服に, 少量のフロセミド $10 \mathrm{mg} /$ 日の静脈内投与 を追加した。

これにより徐々に利尿が見られ，フロセミドによ る治療を継続していたところ，入院第 3 病日にめま い, 嘔気・嘔吐症状が出現。診察上も左右注視方向 性の眼振を認め, 上肢に失調症状を認めた。頭部 CT 検査を施行したところ, 左小脳半球に梗塞性病変を 認め, 補液などに加え, エダラボン点滴治療なども 追加した（図 4 )。脱水状態を避けるため, フロセ ミドの投与に関しては，外来時と同様に内服薬 40 $\mathrm{mg}$ のみで継続加療とした。

その後これらの治療により小脳梗塞に伴う諸症状 は改善傾向を示し，自力での食事摂取が可能となる。 しかし口渇や下腿の浮腫に関しては, その後も変化
が見られなかった。入院後, 体重の減少傾向は見ら れていたが，入院第31病日に胸部 CT 検査を再度行 なったところ，胸水は入院時より増加傾向が見られ た（図 $2-b) 。$

経過中も外来時と同様，収縮期血圧が $80 \mathrm{mmHg}$ 前後と低く，皮膚乾燥，口渇が強いなどの状態から， うっ血性心不全に対し，さらなる利尿薬の追加は， 血圧の低下や脱水状態を生じ，全身状態を悪化させ る可能性も考えられた。このため漢方薬治療を検討 した。

舌は著明に乾燥し, 口渴が見られる一方, 胸水貯 留以外にも四肢に浮腫傾向が見られ，水分の代謝異 常が考えられた。尿量に関しては入院直後 1 日 1200 $\sim 1300 \mathrm{ml}$ 程度であり，自覚的にも少ないとの訴え があった。入院時より和漢診療学的な所見に変化が なく，胃部振水音ははっきりしなかったが，口渇， 心下㾙鞕，小便不利，浮腫傾向などを目標に，他の 内服薬を変更することなく，五苓散エキス顆粒（ツ ムラ $7.5 \mathrm{~g} /$ 日）の投与を開始した。

これにより，特に血圧が変動することなく，徐々 に下腿の浮腫が軽減し，さらにそれまで強く訴えて いた口渇症状が改善した。さらに呼吸状態も安定し， 胸部 CT 検査を再検査したところ，胸水の減少傾向 を認めた（図 2-C)。体動時の呼吸苦なども消失 したため，入院後53日目に自宅退院とするが，その 後も五苓散を継続投与したところ，口渴症状は見ら れず，心不全の悪化も認められなかった。尿量に関 しては尿バルーン抜去後, 蓄尿が十分に行えず, 正 確な量は不明であるが，自覚的な訴えとして尿量の 増加が見られた。

一方, 体重は五苓散投与前 $34.1 \mathrm{~kg}$ から退院時 $33.2 \mathrm{~kg}$ まで $0.9 \mathrm{~kg}$ の減少であり, 小柄な体格であ ることを考慮すれば明らかな減少と見られ，うっ血 性心不全を示唆する諸症状は消失し, 血液検査上も BNP の低下傾向が認められた。

\section{考察}

慢性心不全はガイドラインに示されているように， 慢性の心筋障害により心臟のポンプ機能が低下し, 末梢主要臓器の酸素需要量に見合うだけの血液量を 絶対的にまた相対的に拍出できない状態であり，肺 または体静脈系にうっ血を来たし生活機能に障害を 生じた病態と定義されている1 ギオテンシン・アルドステロン系などの神経内分泌 


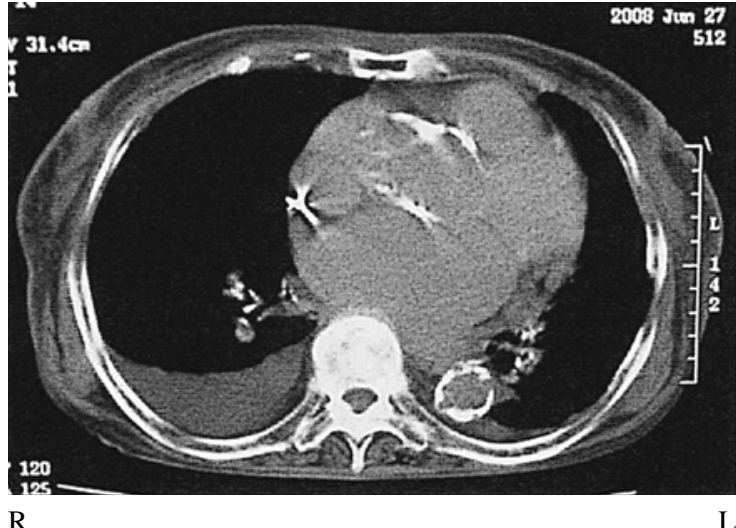

図 $2-a$

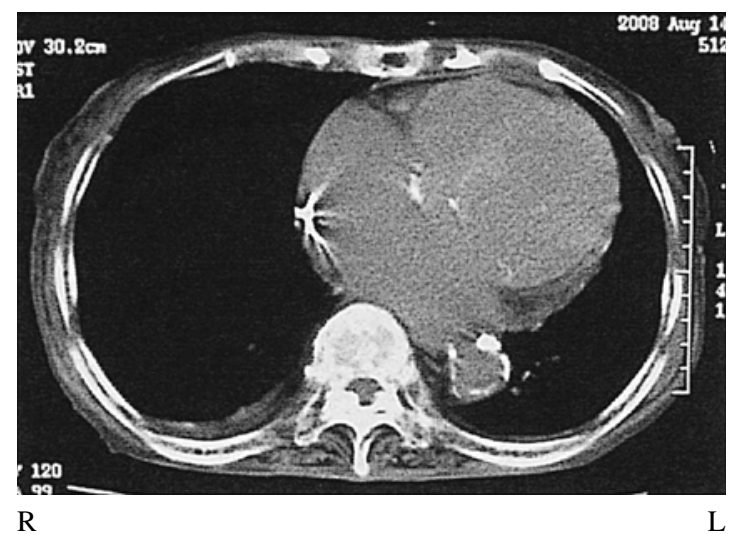

図 2-c

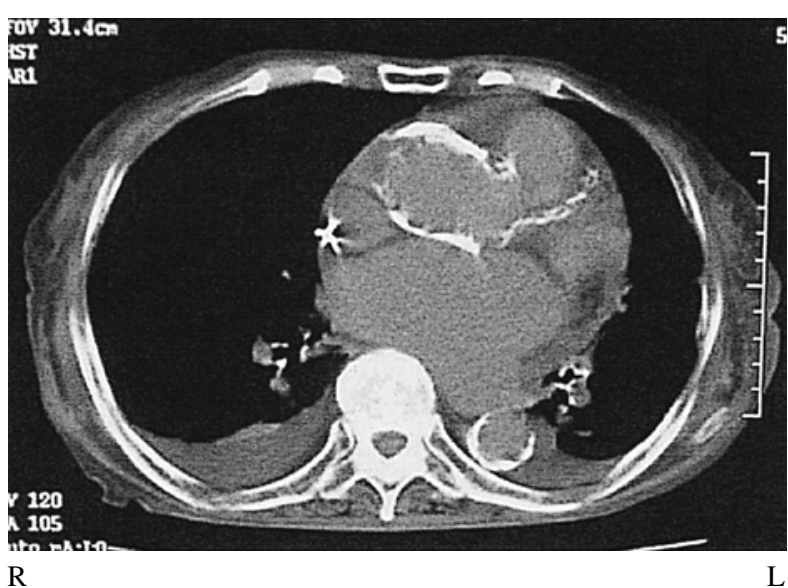

図2-b

図 2 胸部 $\mathrm{CT}$ 検査

入院時，両側に胸水を認め $(\mathrm{a}), 1$ 力月後，胸水はさら に増加した（b)。五苓散を追加したところ，胸水の減少を 認めた (c：五苓散投与開始17日目)。
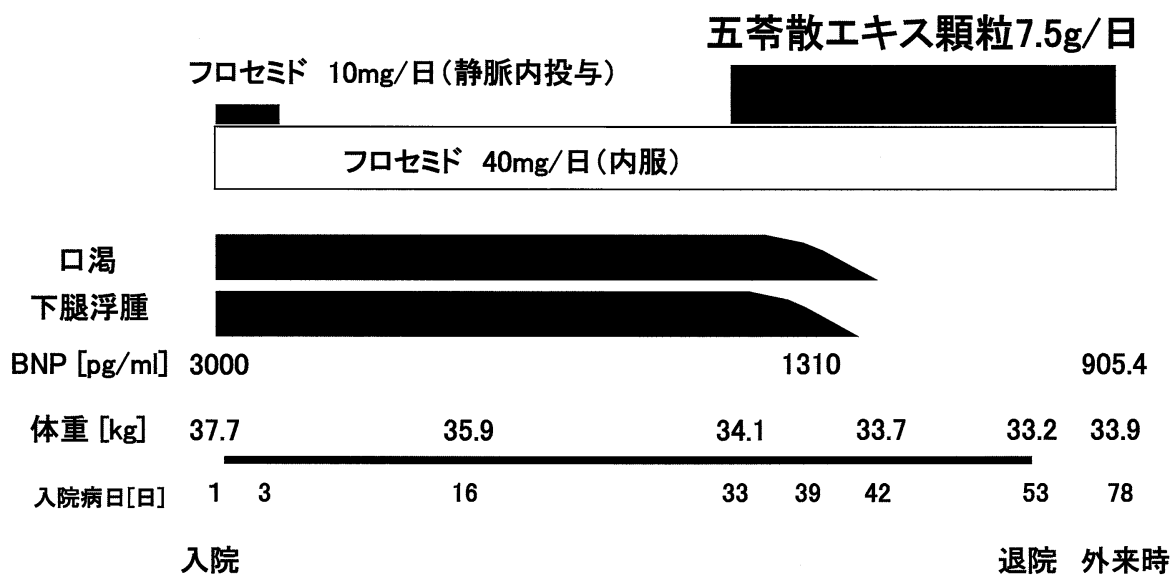

図 3 経過

五苓散の投与後，口渇，下腿浮腫が消失した。

因子が関連した病態としても認識されている。症状 としては左房圧上昇・低心拍出量に基づく左心不全 症状と，右心負荷による浮腫などの右心不全症状に 分けられる。高齢者の慢性心不全の基礎疾患として, 冠動脈硬化症, 弁膜症, 高血圧症, 心筋症などがあ げられ，特に拡張不全による心不全症例の頻度が高 w。
本症例の場合，弁膜疾患を以前から指摘され，さ らに洞不全症候群に対してペースメーカ植込み術も 施行されており，加齢に伴う心機能の低下が進行し ていたと考えられる。症状からは左心不全症状と右 心不全症状の両方が見られており，心機能全般の低 下が考えられた。Framingham Heart Study（FHS）の 心不全基準からもうっ血心不全が存在していること 


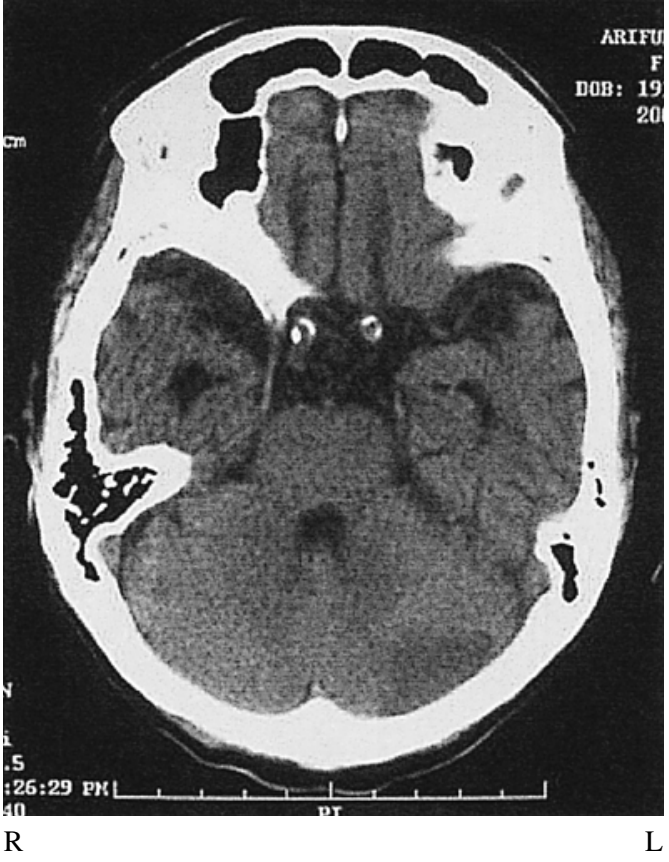

図 4 頭部 CT 検査（入院第 3 病日） 左小脳半球に脳梗塞病変を認めた。

が分かり，さらに American College of Cardiology/ American Heart Association（ACC/AHA）の慢性心不 全の評価と治療に関するガイドラインにおいて，本 症例の状態は心不全のステージ分類からは Stage C と診断された て，食生活の乱れに伴う，塩分制限が不十分であっ たことや，水分摂取もやや多めになっていたことが あげられる。

胸水貯留の治療は原因疾患により異なるが，慢性 心不全の増悪に伴う場合にはフロセミドなどの利尿 薬が第一選択となる。利尿薬は一般的に尿量の増加 による前負荷軽減を目的としているが，本症例のよ うな高歯者の場合には, 脱水, 電解質異常, 耐糖能 低下などの合併症を生じやすく, 慎重な投与が必要 となってくる。また長期的な予後の改善効果は明ら かではない。

またガイドラインにも示されているように，利尿 薬により過度の利尿が生じると, 血液濃縮を生じ, さらには脳血栓症の誘因となりうるとされ，特にへ マトクリット $45 \%$ 以上の血液濃縮では脳血栓の重要 な危険因子であることも知られている。

本症例において，小脳梗塞発症時の血液検査で特 にへマトクリットの上昇は見られておらず，今まで の慢性心不全急性増悪に伴う入院時と同容量のフロ セミドを用いており，小脳梗塞発症との因果関係は
不明である。しかし脳梗塞発症した状況において， 今後の脳梗塞再発を考えた場合, これ以上の西洋薬 の利尿薬の追加はやや難しい状況にあった。

一般に慢性心不全に対する薬剤として, ACE 阻 害薬，アンギオテンシン II 受容拮抗薬（angiotensin II receptor blocker : ARB) , $\beta$ 遮断薬，抗アルドステ ロン薬なども用いられる。また慢性心不全の急性増 悪時の治療として, 全身および肺うっ血を伴う場合 にはループ利尿薬, 硝酸薬, カルペリチド点滴など を行うことが推奨されている。高齢者の慢性心不全 の治療薬としてはACE 阻害薬やARB な゙が, 効 果的とされているものの, 腎機能障害, 高カリウム 血症，症候性低血圧などに留意が必要であるとされ ている。

本症例の場合, New York Heart Association(NYHA) 分類で中等症から重症の状態にあり, 症状の安定化 に対して, 前述の各種薬剤の投与が必要な状態に あった。入院後も血圧の変動はなく, 血行動態的に は安定していたが，通常より収縮期血圧が $80 \mathrm{mmHg}$ 前後と低く, 時おり起立時に立ちくらみ様の症状を 認めるなど，血圧を低下させるような薬剤の追加投 与は行ないにくい状況にもあった。

心不全に対する漢方治療についてはいくつかの報 告があり，心不全を引き起こした原因疾患により方 剂が異なってくる。右心不全が見られる場合に用い られる木防己湯はその 1 つであり ${ }^{3) 4}$, 五苓散も熱証 で尿量減少や浮腫のある症例に効果があるとされて いる ${ }^{3)}$ 。低血圧症に対する漢方薬治療としては起立 性低血圧や起立性調節障害を腎虚, 水滞, 瘀血など の病態が関与していると考え, これらに対し陽証で は五苓散, 苓桂术甘湯などが投与され, 陰証では真 武湯, 半夏白术天麻湯, 八味地黄丸, 当帰药薬散, 補中益気湯などが投与されている5)。しかしいずれ も直接的な血圧上昇作用は考えにくく, 随伴症状の 軽減に対しての効果が期待されている。

本症例の場合, 食事量の低下はなく, 高齢ではあ るが活動的であり，入院時の状態はやや陽証に近い 状態にあると考えられた。小便不利で胸水が貯留し， 水分の過㮃状態が存在する一方で，口渇，皮膚の乾 燥傾向があり，入院後は $37{ }^{\circ} \mathrm{C}$ 前後の微熱が続くな ど，半表半裏の熱を疑わせ，五苓散の適応と考えた。

五苓散は沢瀉，猪苓，获苓，蒼术，桂皮の 5 種類 の生薬から構成されており，病態は少陽病期であり， 
水滞を目標に利水剂として虚実間証に幅広く使われ ている方剂である ${ }^{6}$ 。水をめぐらせ利尿作用を示す 生薬成分に加え，水の停滞を防ぎ，さらに解表駆邪 の働きが合わさって, 急性疾患に対し利水作用を示 し，水の偏在を調節するとされている。

本症例の場合, 入院当初は食事内容が是正された こともあり，体重減少を認めており，さらに五苓散 投与後には西洋薬の内容を変更していないにもかか わらず，胸水が減少し，口渴症状も改善している。 尿量に関しては正確な測定ができなかったため，五 苓散投与前後での変化ははっきりしないが，浮腫の 消失がある一方で，体重減少は少ないながらも，明 らかな減少が見られ, 五苓散の生体内の水分調節作 用により7)，過剩な水分を体外に排出しながらも， 水分の局在化を是正したことが推察される。以前, 我々は胸水貯留を再発する症例に対し，五苓散が有 効であった症例を報告したが，この時も尿量の増加 に比して，体重減少は著明ではなかったことを経験 している8

西洋薬の利尿薬では水の移動に浸透圧が関与して 作用を発現するが，五苓散やその構成生薬である蒼 术は細胞膜の水透過性を調節するアクアポリン水 チャネルを介することが示唆されている妾。この点 からも五苓散がフロセミドなどの利尿薬とは，水分 調節の作用機序が異なり, 漢方薬特有の水分調節作 用を示していることも考えられる。

フロセミドなどの西洋薬による脱水や血圧変動な どの副作用を考慮すると, 五苓散は循環動態への影 響は少なく，本症例のように併用することも有効な 治療法の一つと考えられる。西洋薬の長期投与と同 様に，五苓散の長期投与による問題も考慮する必要 はあるが，作用機序の異なる五苓散の併用により西 洋薬の副作用を軽減し, 効果的な水分調節が期待で
きることも考えられた。

\section{結語}

今回我々は，低血圧を伴う慢性心不全の急性増悪 症例に対し五苓散を投与したところ，浮腫の改善と 胸水貯留の消失を認めた症例を経験した。

慢性心不全に対し，利尿薬はうっ血性心不全の諸 症状を改善するとされるが，本症例のように低血圧 を伴う場合，利尿薬を投与しにくいことが多い。病 態が和漢診療学的診察における水滞を呈している場 合には，五苓散の併用が治療の選択肢の一つになり うる可能性が示唆された。

附記＼cjkstart本稿の概略は，第60回日本東洋医学会学術総 会（2009年 6 月20日＼cjkstart東京）にて発表した。

\section{引用文献}

1) 循環器病の診断と治療に関するガイドライン（慢性心 不全治療ガイドライン, 日本循環器学会, 2010年改訂 版

2 ) Hunt SA : ACC/AHA2005 Guideline for the Diagnosis and Management of Chronic Heart Failure in the Adult, Circulation112，1825-1852，2005

3 ) 桑木崇秀: 漢方診療ハンドブック，76-79, 創元社, 大阪, 1995

4 ）今田屋章：心不全，漢方医学講座，51，60-68，1990

5 ) 寺澤捷年, 喜多敏明, 関矢信康 編集 : EBM 漢方（第 2 版), 20-22, 医歯薬出版, 東京, 2007

6 ) 寺澤捷年：症例から学ぶ和漢診療学, 224, 医学書院, 東京, 1990

7 ) 田代眞一：五苓散の利水作用，腎と透析 (別冊)，26, 34-37, 1989

8 ）松井龍吉：再発した胸水貯留に対し五苓散が有効で あった一症例, 日本東洋医学雑誌，57，339-344，2006

9 ）礒濱洋一郎：炎症・水毒・和漢薬によるアクアポリン 水チャネルの機能調節，漢方と最新治療，17，27-35, 2008 